\section{Gibberellic Acid Promotes Seed Germination in Penstemon digitalis cv. Husker Red}

\author{
Anderson Machado de Mello \\ Programa de Pós-graduacao em Agronomia, Universidade Federal de Santa \\ Maria, Santa Maria, Rio Grande do Sul State, 97105-900, Brazil
}

\author{
Nereu Augusto Streck \\ Departamento de Fitotecnia, Universidade Federal de Santa Maria, Santa \\ Maria, Rio Grande do Sul State, 97105-900, Brazil
}

Erin E. Blankenship
Department of Statistics, University of Nebraska, Lincoln, NE 68583-0963

Ellen T. Paparozzi ${ }^{1}$

Department of Agronomy and Horticulture, University of Nebraska-Lincoln, 377 Plant Sciences, Lincoln, NE 68583-0724

Additional index words. dormancy, seed soak, $\mathrm{GA}_{3}$

\begin{abstract}
Penstemon seed often shows an inconsistent or a low germination percentage. Although most select cultivars are propagated by cuttings, for export to other countries, seed is preferred. Three experiments were conducted to determine if soaking seed in gibberellic acid $\left(\mathrm{GA}_{3}\right)$ would increase seed germination of Penstemon digitalis cv. Husker Red. $\mathrm{GA}_{3}$ concentrations used were $0,10,50,100,200$, and $500 \mathrm{mg} \cdot \mathrm{L}^{-1}$ (first experiment); $0,500,1000$, and $1500 \mathrm{mg} \cdot \mathrm{L}^{-1}$ (second experiment); and 0,500 , and $1000 \mathrm{mg} \cdot \mathrm{L}^{-1}$ (third experiment). The first and second experiments were conducted in a growth chamber, whereas the third experiment was conducted in both a growth chamber and greenhouse with seeds either covered or not covered by the mix. In all experiments, $\mathbf{G A}_{3}$ increased the percentage and rate of seed germination. The $1000 \mathrm{mg} \cdot \mathrm{L}^{-1} \mathrm{GA}_{3}$ was the best treatment. In the third experiment, percentage and rate of seed germination were the highest for seeds grown inside of the growth chamber, probably as a result of the consistency of temperatures and darkness. In the greenhouse, the percentage of seeds that germinated and the rate of germination were similar whether or not the seeds were covered with mix and whether they received either the 500 or $1000 \mathrm{mg} \cdot \mathrm{L}^{-1} \mathrm{GA}_{3}$ treatment.
\end{abstract}

Over the past few years, various penstemons (from $\approx 280$ species) have become increasingly popular as a garden flower. These plants grow and tolerate a wide range of temperatures and have a variety of flower types and colors. Of particular interest to us is Penstemon digitalis cv. Husker Red, because its tall showy flower spikes have potential as a specialty cut flower. Although cuttings are the preferred method of propagating 'Husker Red' penstemon, for locations and regions where cuttings are not readily available, seedlings could be screened and then selected for stock plant production. However, seeds of many Penstemon species possess a dormancy that limits seed germination. As a result, individual germination requirements vary widely both among and within species (Kitchen and Meyer 1991; Meyer et al.,

\footnotetext{
Received for publication 28 Jan. 2009. Accepted for publication 18 Feb. 2009.

We thank Dr. Dale Lindgren for seed, advice on cultural procedures, and critical review of the manuscript.

${ }^{1}$ To whom reprint requests should be addressed; e-mail etp1@unl.edu.
}

1995). In perennial production classes at the University of Nebraska-Lincoln, fresh penstemon seed sown without any soaking will take 4 to 5 weeks to germinate with only a maximum of $50 \%$ success rate (unpublished data).

Gibberellic acid $\left(\mathrm{GA}_{3}, \mathrm{GA}_{4}\right.$, and $\left.\mathrm{GA}_{7}\right)$ has been shown to break dormancy and increase germination in seeds of several genera (Bewley and Black, 1982, 1985), including certain penstemon (Atwater, 1980; Meyer et al., 1995). Using Intermountain region penstemon species, Kitchen and Meyer (1991) working with five concentrations of $\mathrm{GA}_{3}(0$ to $500 \mathrm{ppm}$ ) in combination with a cold treatment $\left(2{ }^{\circ} \mathrm{C}\right)$ found that seeds that were treated with $\mathrm{GA}_{3}$ and stratified (to simulate natural conditions that a seed must endure before germination) had higher germination percentages. Raeber and Lee (1991) soaked seeds of Penstemon parryi in six concentrations of $\mathrm{GA}_{3}$ (0 to $\left.500 \mathrm{ppm}\right)$ for $24 \mathrm{~h}$ and found $87 \%$ to $97 \%$ seed germination. Neither low temperature stratification nor $\mathrm{NaCl}$ soaks were as effective as $500 \mathrm{ppm} \mathrm{GA}_{3}$ for seeds of $P$. parryi. Mexican species such as $P$. harwegii and $P$. gentianoides as well as $P$. barbatus 'Coccineus' germinated without stratification at $21{ }^{\circ} \mathrm{C}$ (Nau, 1996; Way and James, 1998).

Given the desire to grow 'Husker Red' penstemon as a specialty cut flower in a country where cuttings/plugs are not available and difficult to impossible to send from the United States and because seeds of 'Husker Red' are usually sown while fresh (when used for breeding and selection purposes) and often result in uneven seed germination (Lindgren, personal communication) or are reported to take up to 8 weeks for germination (Swayne, 2000), three experiments were conducted to determine if $\mathrm{GA}_{3}$ soaks would promote seed germination to facilitate stock plant establishment.

\section{Materials and Methods}

Two seed germination experiments were conducted in a dark growth chamber in the Plant Science Building at the University of Nebraska, Lincoln, NE (UNL). The first experiment was conducted from 13 to 27 Apr. 2007 and the second from 12 to 26 Aug. 2007. The third experiment was conducted from 23 Sept. to 8 Oct. 2007 in a growth chamber and the UNL double polyethylene greenhouses. Fresh seeds of Penstemon digitalis 'Husker Red' were obtained from Dr. Dale Lindgren's breeding program and were soaked for $24 \mathrm{~h}$ in $50 \mathrm{~mL}$ of one of the following treatments: $0,10,50,100,200$, and 500 [first experiment; used by Raeber and Lee (1991) on $P$. parryi]; 0, 500, 1000, and 1500 (second experiment); and 0, 500, and 1000 (third experiment) $\mathrm{mg} \cdot \mathrm{L}^{-1} \mathrm{GA}_{3}$. All seed mixtures were gently swirled at the beginning, middle, and end of the 24-h soak period in each experiment. Floating (empty) seeds were discarded. Seed mixtures were then filtered and rinsed under cold distilled water for $2 \mathrm{~min}$.

In the first and second experiments, 15 seeds were placed in a small petri dish $(5 \mathrm{~cm})$ with No. 2 Whatman filter paper, which was saturated with $1 \mathrm{~mL}$ of distilled deionized (d/ d) water initially and then watered as needed. There were 15 petri dishes per treatment placed randomly across four shelves in a dark growth chamber at $21 \cdot 3{ }^{\circ} \mathrm{C}$.

In the third experiment, seeds were soaked and then sown into six packs (128 cells per tray; each cell holds $80 \mathrm{~mL}$ of mix) such that each treatment had eight cells with one seed per cell. Seeds were sown by either placing them on top of the mix (uncovered) or lightly covered by the mix (1:1 peat vermiculite by volume). There were eight flats total with two blocks per flat. Six flats were placed in the greenhouse $\left(24\right.$ to $32{ }^{\circ} \mathrm{C}$ day/21 to $24{ }^{\circ} \mathrm{C}$ night) and two flats were placed in a dark growth chamber $\left(21 \cdot 3^{\circ} \mathrm{C}\right)$. All flats were covered with a plastic dome and each cell was watered with $4 \mathrm{~mL}$ of $\mathrm{d} / \mathrm{d}$ water initially and then as needed.

For Expts. 1 and 2, seeds were observed daily for germination and were considered germinated when the radical was visible. For Expt. 3, seeds were considered germinated when the cotyledons appeared. 
The experimental design for the first and second experiments was a completely randomized design. The third experiment was a randomized complete block design with the covered and uncovered planting treatments in the greenhouse or in the growth chamber analyzed as four separate experiments. Thus, there were 12 replications for each-the uncovered and covered in the greenhouse and there were four replications for each - the uncovered and the covered in the growth chamber.

All experimental data were subjected to a Shapiro-Wilk test of normality to determine if the data needed to be transformed. Residuals versus predicted values were also plotted to assess the assumption of constant variance. Because the variance was found to be constant and the seed count data were normally distributed, the data were not transformed. Statistical analyses were then conducted using analysis of variance implemented in SAS PROC MIXED (SAS Institute, 2006) identifying significant differences through the use of contrasts. Least square means were expressed as percent germination.

The number of germinating seeds out of 15 for Expt. 1 and out of 10 for Expts. 2 and 3 was also modeled as a function of time using a logistic model implemented in SAS PROC NLMIXED (SAS Institute, 2006). From the fitted models, time until $50 \%$ germination (T50) was calculated, and differences between T50s for different levels of $\mathrm{GA}_{3}$ were calculated.

\section{Results and Discussion}

Expt. 1. Gibberellic acid increased seed germination and the rate of germination as compared with the control (Fig. 1; Table 1). The increase was directly proportional to the increase in $\mathrm{GA}_{3}$ concentrations within the range used. All concentration of $\mathrm{GA}_{3}$ reduced the number of days to $50 \%$ seed germination, but particularly $500 \mathrm{mg} \cdot \mathrm{L}^{-1}(12 \mathrm{~d})$ as compared with the control ( $23 \mathrm{~d}$; water soak only) (Table 1). However, total germination percentages were not much higher than $50 \%$ of the seed sown.
Expt. 2. As in Expt. 1, all $\mathrm{GA}_{3}$ treatments were effective for increasing seed germination when compared with the control (Fig. 2). Moreover, seeds from the control treatment $\left(0 \mathrm{mg} \cdot \mathrm{L}^{-1}\right)$ did not start to germinate until 5 $\mathrm{d}$ after the beginning of the experiment, whereas seeds from all other $\mathrm{GA}_{3}$ treatments started to germinate after $48 \mathrm{~h}$. The highest percentage of seed germination occurred when seeds were soaked with $1000 \mathrm{mg} \cdot \mathrm{L}^{-1}$ $\mathrm{GA}_{3}$ (almost $100 \%$ germination after $8 \mathrm{~d}$ ). Again, all $\mathrm{GA}_{3}$ treatments were effective for increasing the speed of seed germination by 7 to $13 \mathrm{~d}$ (Table 2). Seeds germinated quicker when they were soaked in either 1000 or 1500 $\mathrm{mg} \cdot \mathrm{L}^{-1} \mathrm{GA}_{3}$ (Days 4 and 5).

Expt. 3. All levels of $\mathrm{GA}_{3}$ were again effective for increasing seed germination when compared with the control treatment (Table 3). In all treatments, the speed of germination and the number of seeds that germinated was higher for plants grown in the growth chamber compared with plants in the greenhouse (for figures, see Mello, 2009).

All concentrations of $\mathrm{GA}_{3}$, except the control, were effective for increasing the speed of germination when seeds were either not covered or were covered with mix (Table $3)$. When seeds were not covered with mix, seeds soaked in either the 500 or $1000 \mathrm{mg} \cdot \mathrm{L}^{-1}$ $\mathrm{GA}_{3}$ germinated in half the time compared with the control. When seeds were covered with mix, seeds soaked in $1000 \mathrm{mg} \cdot \mathrm{L}^{-1} \mathrm{GA}_{3}$ germinated more rapidly.

Seed flats placed in the greenhouse were slower to germinate than all the seeds that were grown in the dark growth chambers (Table 3). In the greenhouse, it did not matter whether the seeds were covered with mix; either $\mathrm{GA}_{3}$ concentration caused seeds to germinate faster. There was no difference in speed of germination between the two concentrations of $\mathrm{GA}_{3}$.

In these experiments, we have shown that 24-h GA 3 soaks increase the number of seeds germinated and the speed of seed germination for 'Husker Red' penstemon. Similar increases in germination when seeds were soaked at similar concentrations as those used in this research have been shown to

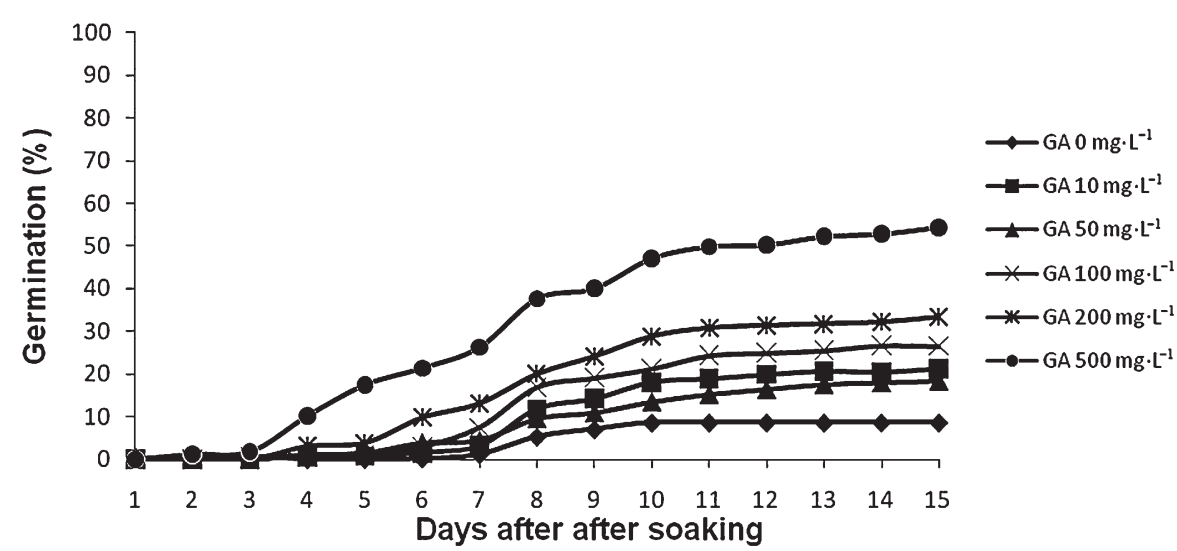

Fig. 1. Percentage of Penstemon digitalis 'Husker Red' seeds that germinated each day after soaking for 24 $\mathrm{h}$ in $0,10,50,100,200$, or $500 \mathrm{mg} \cdot \mathrm{L}^{-1}$ gibberellic acid $\left(\mathrm{GA}_{3}\right)$. Seeds were sown on moistened filter paper in petri dishes and germinated in a dark growth chamber at 21 to $24{ }^{\circ} \mathrm{C}$. effectively increase seed germination for a wide variety of seeds such as Verbena bonariensis (Kornegay and Doubrava, 2006), Sesamum indicum (Kyauk et al., 1995), Trichocereus terscheckii (Ortega-Bae and Rojas-Aréchig, 2007), Sesleria varia (Castiglioni et al., 2004), Sesamum indicum (Kyauk et al., 1995), Ferula gummosa and Teucrium polium (Nadjafi et al., 2005), black mulberry (Koyuncu, 2005), Cyclocarya paliurus (Fang et al., 2006), Prunus avium (Çetinbaş and Koyuncu, 2006), Gautheria procumbens (Ruchala, 2002), and Galeopsis speciosa (Karlsson et al., 2006).

So the question arises as to whether Penstemon digitalis seeds possess dormancy. According to Nold (1999) in the genus Penstemon, dormancy can be removed by subjecting the seeds to temperatures below $\approx 7{ }^{\circ} \mathrm{C}\left(45^{\circ} \mathrm{F}\right)$ for weeks or months depending on the species. Gibberellins $\left(\mathrm{GA}_{3}, \mathrm{GA}_{4}\right.$, and $\mathrm{GA}_{7}$ ) have been shown to break dormancy in numerous genera of seeds (Bewley and Black, 1982, 1985), including Penstemon (Atwater, 1980). Kitchen and Meyer (1991) working with $50,150,250$, and $500 \mathrm{mg} \cdot \mathrm{L}^{-1}$ $\mathrm{GA}_{3}$ recommend treatments with $\mathrm{GA}_{3}$ to remove seed dormancy or shorten the chilling requirement for many, but not all, species of Penstemon and recommended the use of gibberellins together with other treatments such as stratification or scarification to increase the effects of $\mathrm{GA}_{3}$ in breaking dormancy. However, according to Atwater (1980), plants in the Scrophulariaceae family to which Penstemon belongs have seeds in which the endosperm surrounds the embryo and occupies up to half of the seed. In our data, there was a trend that, over experiments (and thus over time), the percent germination increased for the same treatment, particularly the $0 \mathrm{mg} \cdot \mathrm{L}^{-1} \mathrm{GA}_{3}$ treatment. One reason may be that these seeds were undergoing afterripening. Another possibility could be an increasing permeability of the seedcoat because penstemons have been shown to have thin, fragile seedcoats (Atwater, 1980). However, 'Husker Red' seeds, which were acid-scarified for 15 to $60 \mathrm{~min}$ at 15 -min intervals, did not show improved germination (Mello and Paparozzi, unpublished data) Thus, if there is dormancy, it is probably a physiological one, endodormancy (Baskin and

Table 1. The actual percentage of seed germination after $15 \mathrm{~d}$ and the estimate of the number of days it would take to $50 \%$ seed germination when seeds of Penstemon digitalis 'Husker Red' were soaked for $24 \mathrm{~h}$ in varying concentrations of $\mathrm{GA}_{3}{ }^{\mathrm{z}}$

\begin{tabular}{ccc}
\hline $\mathrm{GA}_{3}\left(\mathrm{mg} \cdot \mathrm{L}^{-1}\right)$ & Germination $(\%)$ & Estimate $($ days $)$ \\
\hline 0 & 8.63 & $22.83 \pm 0.84$ \\
10 & 21.18 & $18.11 \pm 0.34$ \\
50 & 18.43 & $19.6 \pm 0.50$ \\
100 & 26.47 & $17.00 \pm 0.30$ \\
200 & 33.33 & $15.82 \pm 0.23$ \\
500 & 54.31 & $12.10 \pm 0.13$ \\
\hline
\end{tabular}

${ }^{\mathrm{z}}$ All pairwise comparisons between treatments were significantly different from each other at $\mathrm{Pr}$ $<0.01$. 


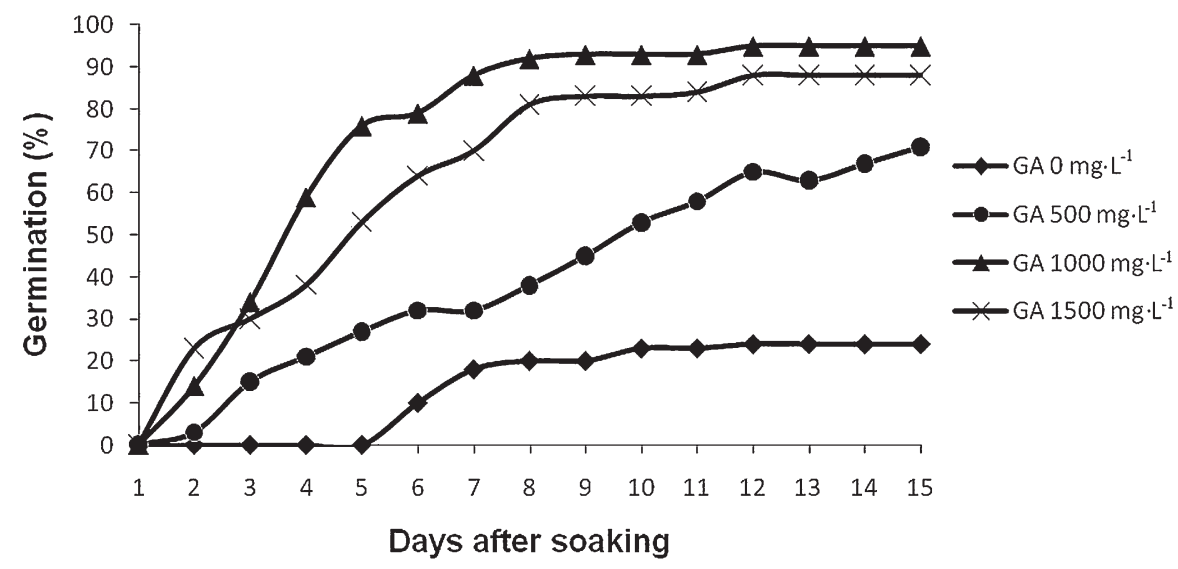

Fig. 2. Percentage of Penstemon digitalis 'Husker Red' seeds that germinated each day after soaking for 24 $\mathrm{h}$ in $0,500,1000,1500 \mathrm{mg} \cdot \mathrm{L}^{-1}$ gibberellic acid $\left(\mathrm{GA}_{3}\right)$. Seeds were sown on moistened filter paper in petri dishes and germinated in a dark growth chamber at 21 to $24{ }^{\circ} \mathrm{C}$.

Table 2. The actual percentage of seed germination after $15 \mathrm{~d}$ and the estimate of the number of days it would take for $50 \%$ seed germination when seeds of Penstemon digitalis 'Husker Red' were soaked for $24 \mathrm{~h}$ in varying concentrations of $\mathrm{GA}_{3}{ }^{\mathrm{z}}$

\begin{tabular}{ccc}
\hline $\mathrm{GA}_{3}\left(\mathrm{mg} \cdot \mathrm{L}^{-1}\right)$ & Germination (\%) & Estimate (days) \\
\hline 0 & 24.00 & $17.94 \pm 0.82$ \\
500 & 71.00 & $10.19 \pm 0.25$ \\
1000 & 95.00 & $4.17 \pm 0.17$ \\
1500 & 88.00 & $5.43 \pm 0.21$ \\
\hline
\end{tabular}

${ }^{\mathrm{z}}$ All pairwise comparisons between treatments were significantly different from each other at Pr $<0.01$.

Baskin, 1998; Bradbeer, 1988; Raghavan, 2000), that could be released by a gibberellin soak.

Light can either stimulate or inhibit seed germination. As expected, seeds in the growth chamber that did not need to push through the growth medium germinated faster than covered seeds. In the third experiment, our results showed that seeds flats placed in the greenhouse were slower to germinate than seeds that were grown in the completely dark growth chambers. Evensen and Loy (1978) had some similar results working with seeds of a monogenic recessive dwarf inbred line of watermelon. They found that $\mathrm{GA}_{3}$ increased the rate of germination, but light decreased the rate of seed germination. The authors suggested that this was the result of lipid degradation promoted by $\mathrm{GA}_{3}$, thus providing solutes necessary for seed germination. Application of $\mathrm{GA}_{3} \quad(500$ $\mathrm{mg} \cdot \mathrm{L}^{-1}$ ) to seeds that were incubated at alternating temperatures $\left(20 / 30{ }^{\circ} \mathrm{C}\right.$ for $16 / 8$ h) in light did not enhance germination of Echinacea angustifolia (Macchia et al., 2001). Thus, the consistent warm, not hot, temperatures in the growth chamber may have aided germination. For Penstemon digitalis cv. Husker Red, we hypothesize that the effect of darkness, consistency of moisture, and warm temperature together with $\mathrm{GA}_{3}$ soaks helped seeds to overcome endodormancy.

In conclusion, soaking seeds of Penstemon digitalis $\mathrm{cv}$. Husker Red in $1000 \mathrm{mg} \cdot \mathrm{L}^{-1}$ $\mathrm{GA}_{3}$ for $24 \mathrm{~h}$ increases the rate and number of germinating seeds whether seeds are grown in petri dishes in a dark, warm growth chamber, or a soilless mix with a clear plastic dome over the flat in a warm greenhouse. Soaking seeds in either 500 or $1000 \mathrm{mg} \cdot \mathrm{L}^{-1}$ $\mathrm{GA}_{3}$ and then sowing them in a soilless mix either lightly covered or on the top of the mix in a flat covered with a plastic dome in the greenhouse will also increase the number and rate of germinating seeds. Over all experi-

Table 3. The actual percentage of seed germination after $15 \mathrm{~d}$ and the estimate of the number of days it would take for $50 \%$ seed germination when seeds of Penstemon digitalis 'Husker Red' were soaked for $24 \mathrm{~h}$ in varying concentrations of GA and then sown in soilless mix. ${ }^{\mathrm{z}}$

\begin{tabular}{|c|c|c|c|c|c|c|c|c|}
\hline \multirow[b]{3}{*}{$\begin{array}{l}\mathrm{GA}_{3} \\
\left(\mathrm{mg} \cdot \mathrm{L}^{-1}\right)\end{array}$} & \multicolumn{4}{|c|}{ Greenhouse } & \multicolumn{4}{|c|}{ Growth chamber } \\
\hline & \multicolumn{2}{|c|}{ Uncovered } & \multicolumn{2}{|c|}{ Covered } & \multicolumn{2}{|c|}{ Uncovered } & \multicolumn{2}{|c|}{ Covered } \\
\hline & $\begin{array}{c}\text { Germination } \\
(\%)\end{array}$ & $\begin{array}{c}\text { Estimate } \\
\text { (days) }\end{array}$ & $\begin{array}{c}\text { Germination } \\
(\%)\end{array}$ & $\begin{array}{c}\text { Estimate } \\
\text { (days) }\end{array}$ & $\begin{array}{c}\text { Germination } \\
(\%)\end{array}$ & $\begin{array}{c}\text { Estimate } \\
\text { (days) }\end{array}$ & $\begin{array}{c}\text { Germination } \\
(\%)\end{array}$ & $\begin{array}{c}\text { Estimate } \\
\text { (days) }\end{array}$ \\
\hline \multirow[t]{2}{*}{0} & 50.00 & \pm 15.68 & $40.63^{*}$ & \pm 17.94 & 45.83 & \pm 14.77 & 21.88 & \pm 26.68 \\
\hline & & 2.35 & & 3.36 & & 0.40 & & 2.98 \\
\hline \multirow[t]{2}{*}{500} & 100.00 & \pm 5.87 & $46.88 *$ & \pm 12.92 & $56.25 *$ & \pm 12.29 & $45.83 *$ & \pm 14.09 \\
\hline & & 0.43 & & 1.03 & & 0.45 & & 0.38 \\
\hline \multirow[t]{2}{*}{1000} & 84.38 & \pm 7.43 & 75.00 & \pm 7.06 & $53.13 *$ & \pm 12.74 & $44.79 *$ & \pm 13.85 \\
\hline & & 0.38 & & 0.43 & & 0.35 & & 0.43 \\
\hline
\end{tabular}

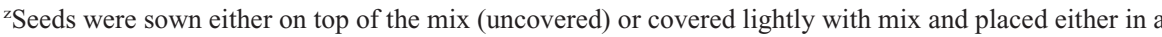
growth chamber or the greenhouse. Unless indicated by an asterisk, all pairwise comparisons between treatments were significantly different from each other at $\operatorname{Pr}<0.01$.

ments, seeds soaked in a high concentration of $\mathrm{GA}_{3}$ consistently gave greater than $50 \%$ germination within 2 weeks.

\section{Literature Cited}

Atwater, B.R. 1980. Germination, dormancy and morphology of the seeds of herbaceous ornamental plants. Seed Sci. and Technol. 8:523573.

Baskin, C.C. and J.M. Baskin. 1998. Seeds: Ecology, biogeography, and evolution of dormancy and germination, p. 27-42. Academic Press, New York, NY.

Bewley, J.D. and M. Black. 1982. Physiology and biochemistry of seeds in relation to germination. Volume 2. p. 60-198. Springer-Verlag Inc., New York, NY.

Bewley, J.D. and M. Black. 1985. Seeds: Physiology of development and germination, p. 175236. Plenum Press, New York, NY.

Bradbeer, J.W. 1988. Seed dormancy and germination, p. 38-80. Chapman and Hall, London, UK.

Castiglioni, A., A. Colombo, and A. Tosca. 2004. Evaluation of germination capacity and priming techniques in Selsleria varia, a plant for restoration of calcareous grasslands. $27 \mathrm{th}$ International Seed Testing Symposium, Budapest; Hungary; 17-19 May. p. 122 (abstr.).

Çetinbaş, M. and F. Koyuncu. 2006. Improving germination of Prunus avium L. seeds by gibberellic acid, potassium nitrate and thiourea. Hort. Sci. (Prague) 33:119-123.

Evensen, K.B. and J.B. Loy. 1978. Effects of gibberellic acid and gold light on germination, enzyme activities, and amino acid pool size in a dwarf strain of watermelon. Plant Physiol. 62:6-9.

Fang, S., J. Wang, Z. Wei, and Z. Zhu. 2006 Methods to break seed dormancy in Cyclocarya paliurus (Batal). Iljinskaja. Scientia Hort. 110 305-309.

Karlsson, L.M., J.A.L. Ericsson, and P. Milberg. 2006. Seed dormancy and germination in the summer annual Galeopsis speciosa. Weed Res. 46:353-361.

Kitchen, S.G. and S.E. Meyer. 1991. Seed germination of Intermountain penstemons as influenced by stratification and $\mathrm{GA}_{3}$ treatments. $\mathrm{J}$. Environ. Hort. 9:51-56.

Kornegay, J. and N. Doubrava. 2006. Friends of the J.C. Raulston Arboretum Newsletter. Bul. 10, No. 1. North Carolina State University, Raleigh, $\mathrm{NC}$

Koyuncu, F. 2005. Breaking seed dormancy in black mulberry (Morus nigra L.) by cold stratification and exogenous application of gibberellic acid. Acta Biol Cracov Bot. 47: 23-26.

Kyauk, H., N.W. Hopper, and R.D. Brigham. 1995. Effects of temperature and presoaking on germination, root length and shoot length of sesame (Sesamum indicum L.). Environ. Exp. Bot. 35:345-351.

Macchia, M., L.G. Angeline, and L. Ceccarini. 2001. Methods to overcome seed dormancy in Echinacea angustifolia DC. Scientia Hort. 89: 317-324.

Mello, A.M. 2009. Vernalization and gibberellic acid in the germination and development of Penstemon digitalis cv Husker Red. PhD Diss. Federal University of Santa Maria, Brazil.

Meyer, S.E.S.G.K. and S.L. Carlson. 1995. Seed germination timing patterns in Intermountain 
Penstemon (Scrophulariaceae). Amer. J. Bot. 82:377-389.

Nadjafi, F., M. Bannayan, L. Tabrizi, and M Rastgoo. 2005. Seed germination and dormancy breaking techniques for Ferula gummosa and Teucrium polium. J. Arid Environ. 64:542-547.

Nau, J. 1996. Ball perennial manual: Propagation and production. Ball Publishing Co., Batavia, IL.

Nold, R. 1999. Penstemons. Timber Press, Portland, OR.
Ortega-Bae, P. and M. Rojas-Aréchig. 2007. Seed germination of Trichocereus terscheckii (Cactaceae): Light, temperature and gibberellic acid effects. J. Arid Environ. 69:169-176.

Raeber, A.C. and C.W. Lee. 1991. Gibberellic acid, temperature, light, stratification, and salinity affect germination of Penstemon parryi seed. HortScience 26:1535-1537.

Raghavan, V. 2000. Developmental biology of flowering plants, p. 292-303. Springer-Verlag Inc., New York, NY.
Ruchala, S.L. 2002. Propagation of several native ornamental plants MS Thesis. University of Maine, Orono.

SAS Institute. 2006. Statistical analysis system for mixed models. SAS Institute, Cary, NC.

Swayne, J. 2000. The penstemons. Seed germination methodology. Feb. 2009. <http://tomclothier. hort.net/page $08 . h$ tml $>$.

Way, D. and P. James. 1998. The gardener's guide to growing penstemons. Timber Press, Portland, OR. 